Accountability and legitimacy of NGOs under authoritarianism: the case of China

Jude Howell $^{\text {a* }}$, K. R. Fisher ${ }^{\mathrm{b}}$, X. Shang ${ }^{\mathrm{b}}$

${ }^{a}$ Department, London School of Economics and Political Studies, United Kingdom;

${ }^{b}$ Social Policy Research Centre, UNSW Sydney, Australia

Email: j.a.howell@1se.ac.uk; $\underline{\text { Karen.fisher@unsw.edu.au; }}$

Xiaoyuan.shang@unsw.edu.au 


\title{
Accountability and legitimacy of NGOs under authoritarianism: the case of China
}

\begin{abstract}
$\underline{\text { ABSTRACT }}$
How NGOs craft accountability and legitimacy in authoritarian states is poorly understood. We put forward a framework of analysis for capturing the processes of making accountability and legitimacy. We introduce the ideas of first and second-order accountability and stocks of accountability capital. In authoritarian regimes, building second-order accountability through the accumulation of stocks of accountability is crucial for NGOs' survival and organisational development and as a path towards gaining first-order accountability. Drawing on a decade of field-work on child welfare NGOs in China from 2007-2017, we select three case-studies with long operational trajectories to illustrate processes of crafting legitimacy and accountability. The research contributes empirically and theoretically to the understanding of accountability in NGOs in authoritarian states through the novel analytic framework and case-study of China.
\end{abstract}

Keywords: accountability, legitimacy, NGOs, authoritarianism, China, child welfare.

Accountability is hard for NGOs to build but easily broken. The sexual exploitation scandal engulfing Oxfam and Save the Children in early 2018 and the subsequent loss of public confidence and funds testify to this (International Development Committee 2018). Building effective accountability systems is vital for ensuring legitimacy claims are upheld and that service delivery failures are avoided (World Bank 2004). Whilst in liberal democracies legitimacy is particularly important for newly founded NGOs, or for legitimacy repair as with Oxfam (Suchman, 1995), in authoritarian regimes this is often even more crucial given the constant shadow of state control and the relative newness of the concept of NGOs. In authoritarian contexts the capacity of NGOs to build accountability that bolsters their legitimacy amongst donors, government and the public can be crucial to their survival and growth. Yet the salience and processes of building accountability in the development of NGOs under authoritarian rule is poorly understood. 
It is argued that in authoritarian regimes like China, NGOs often face considerable barriers to gaining and maintaining legal status as registered social organisations, which would entitle them to engage in first-order accountability processes arising out of registration. Instead they build 'second-order' accountability through the incremental, ongoing accumulation of stocks of accountability capital, which is crucial for their legitimacy, survival and organisational development. This second-order accountability compensates for a lack of opportunities for first-order accountability afforded to registered social organisations. It matters for attracting donors and service users as respectively alternative funding sources and as a support base. Whilst in democratic societies, second-order accountability is also important for maintaining legitimacy, in authoritarian regimes it also serves as a path to achieving first-order accountability. It also matters for registered NGOs to maintain their legal status. This is not just because legal status is discretionary and subject to political winds, but also because it does not address all dimensions of accountability such as professional, user and democratic accountabilities. Both first-order and second-order accountability rely on formal accountability processes such as funder and auditing reports and informal accountability processes such as positive media coverage and informal government recognition.

The article begins with a theoretical overview of the literature on NGOs, accountability and legitimacy, highlighting the gaps on authoritarian regimes and the barriers facing NGOs in crafting accountability and fostering legitimacy. It then puts forward an analytic framework for capturing the processes whereby NGOs in an authoritarian regime such as China accumulate stocks of accountability capital and use these to justify their claims to legitimacy. In doing so, it does not seek to prove direct causality between particular accountability strategies and outcomes, not only because of the methodological difficulty of proving attribution but also because actual outcomes are shaped by multiple contextual factors such as political economy and the history of civil society-state relations. It then illustrates these processes through reference to three case-studies of child welfare groups. It concludes by drawing together key findings and considering the theoretical contribution of the analysis.

\section{Theoretical background}

Accountability is a contested concept infused with differential relations of power. It 
invokes key questions around who can demand accountability, from whom, for what, and how. When applied to NGOs, the analysis of accountability becomes complex as there are multiple actors with varying power to seek accountability and enforce sanctions (Edwards and Hulme 1995; Najam 1996; Willems and Van Dooren 2007). These actors include central and local government, institutional and individual donors, international development agencies, service users, NGO staff and the general public (Willems and Van Dooren 2007). Furthermore, accountability is multi-dimensional (Mattei 2009), covering financial, managerial, professional, societal, democratic and user accountability. The uneven power relations between different actors demanding accountability in turn lead to hierarchies of accountability, whereby certain dimensions of accountability are prioritised over others (Goetz and Jenkins 2005, Mattei 2009).

The ideas of accountability and legitimacy are closely related, though they are often discussed as separate concepts and mainly pertain to governments, yielding discrete sub-fields of literature (Alagappa 1995; Holbig 2013; Kailitz 2013). As Suchman (1995) suggests, legitimacy encompasses both evaluative and cognitive dimensions: 'Legitimacy is a generalised perception or assumption that the actions of an entity are desirable, proper, or appropriate within some social constructed system of norms, values, beliefs and definitions'. This definition allows both for contextual variations in norms and values, and the public's and government's perceptions of NGOs. These are particularly pertinent in rapidly changing socio-economic contexts such as China, where public and government mistrust of NGOs prevails and norms and values are shifting (Lu 2009). Though accountability can bolster legitimacy by supporting claims made, the interrelations between the two concepts can also be problematic. Not all accountability fosters legitimacy claims whilst factors other than accountability can also bolster legitimacy. In some contexts gaining legitimacy from the government could weaken public trust in NGOs where governments are seen as corrupt (Morcol and Muducamura 2014). Where NGOs are relatively unknown, as in China, government approval of an $\mathrm{NGO}$, even informal, can be reassuring to the public and donors ( $\mathrm{Lu}$ 2009). Foreign support to NGOs can bolster the legitimacy of NGOs in the public's eyes but weaken it from the government's perspective. Just as accountability systems can favour particular dimensions of accountability, so too can they favour gaining the legitimacy of more powerful actors over others.

With the exponential growth and influence of NGOs from the 1990s mounting concern amongst policy-makers generated a sub-field of research about the 
accountability and legitimacy of NGOs, predominantly in democratic regimes, (Bebbington et al 2008; Bendell and Cox 2006; Edele 2005; Scholte 2011). This yielded numerous typologies of accountability, highlighted the multi-dimensionality of accountability and generated numerous practical manuals and reports dedicated to evaluation and monitoring (Atack 1999; Charnovitz 2007; Ebrahim 2003; Edwards and Hulme 1995; Douthwaite et al 2006; Mattei 2009; Kilby 2006). It also stimulated research on the importance of participation and empowerment for realising user accountability (Bovaird 2007; Brett 2003; Cornwall and Gaventa 2000; Speer 2012; World Bank 2004). However, there remain significant gaps in the literature, namely, insufficient attention to the relationship between accountability and legitimacy, the processes of building accountability, and NGO accountability and legitimacy in authoritarian regimes.

First, in the field of NGOs the relationship between accountability and legitimacy claims is under-theorised. Accountability gives substance to legitimacy claims by providing evidence. As Hilhorst (2003: 128) notes in her ethnography of NGOs in the Philippines, accountability is a 'device for legitimation'. NGOs' legitimacy to provide services, advocate, or influence policy rests on their multitude of claims. These might include claims of being value-based organisations, professional, competent and well governed. Accountability mechanisms such as financial auditing, reporting, staff appraisal and user feedback channels are some of the formal accountability processes used to justify and monitor NGOs' legitimacy claims. However, as Joshi (2013: S30-33; S44-45) argues in her review of accountability initiatives, not only is there limited evidence of the direct links between accountability initiatives and impact of services, but the multiplicity of historical, political and social factors shaping accountability make direct attribution difficult.

Second, there is a paucity of empirical research on the processes of building accountability and how these shape accountability dimensions that are prioritised. Accountability processes lead to hierarchies of accountability, with typically financial and managerial accountability taking precedence over democratic or user accountability. Multiple stakeholders making demands for accountability have varying degrees of power and means to sanction, with donors' interests tending to prevail over less organised stakeholders such as users (Goetz and Jenkins 2005; Kilby 2006). These power relations in turn are infused with norms and values that combine to marginalise certain voices. Making accountability is thus an iterative, continuous and contentious 
process with consequences for accountability hierarchies and the legitimacy endowed by different actors.

The third gap in the literature concerns the dearth of theoretical and empirical research on NGO accountability and legitimacy in authoritarian regimes. In most conventional treatment, accountability relates to liberal democratic governments, citizens and electoral processes (Anderson 2009; Atack 1999; Goetz and Jenkins 2005). However, authoritarian regimes have specific features that pose particular challenges to accountability and legitimacy and require a different analytic approach. Unlike liberal democracies, authoritarian regimes lack key ex-ante elements for realising accountability (Bueno de Mesquita et al 2003; Brooker 2000; Gandhi 2008; Ma 2009; Wintrobe 1998). Typically, they lack judicial independence, have weaker civil societies, government-controlled media, and poor transparency. Citizens' civil and political rights to freedom of expression and association lack constitutional guarantees (Cassani 2017; Dukalskis and Gerschewski 2017). The regulatory environment governing NGOs is typically highly restrictive and discretionary (ICNL 2016). Unregistered civic groups are at constant risk of surveillance and closure, thwarting their development. Authoritarian regimes also often lack intermediary organisations that liaise and negotiate with government and develop self-regulation mechanisms. This institutional fabric not only affects citizens' ability to hold governments to account, but also the context within which NGOs can develop accountability and legitimacy (Burnell 2006).

Finally, NGOs operate in an environment of general repression, subject to ongoing harassment by security agencies and potential closure. Unregistered groups are often forced underground, or if operating at the surface, have a limited life-span and scale. Even if they do achieve legal status, their situation remains vulnerable to changing government policies, political winds and episodic crack-downs on NGOs. In the past 15 years various countries, democratic and non-democratic, such as Russia, India, Hungary, Egypt and China have tightened their controls over foreign funding to NGOs, fearing that such support could destabilise their governments (Dauce 2014; Dupuy et al, 2016; ICNL 2016; Howell 2015; Shieh 2017). Maintaining accountability and legitimacy through second-order accountability remains crucial to the continuing registration and survival of NGOs, whether registered or not.

These features of authoritarianism apply to China, with implications for accountability processes. First, China lacks a civil society sufficiently confident in its security to criticise the regime, an independent media, open sources of information or an 
independent legal system guaranteeing civil and political rights (Edele 2005; White et al 1996). In the last decade, the spread of social media and new technologies has enabled citizens to exchange non-official information, comment on public issues and expose state corruption (Ma 2012; Xu 2012; Yang 2006). However, the state is quick to censor information through firewalls and other means. China thus lacks the expected liberal democratic pre-conditions for realising accountability.

Despite this, it is often asserted that China has many unregistered NGOs and civic groups above-county level providing services, legal advice and rights-based work that far outnumber registered organisations (Wang and Sun 2010)i. Unregistered groups operated in legal limbo for several decades and were constantly at risk of potential closure due to lack of legal registration. The growth of unregistered citizens' groups, particularly during the $\mathrm{Hu}-\mathrm{Wen}$ regime, was partly due to insufficient state capacity to monitor and contain NGOs, partly due to the emergence of new needs for services not yet covered by registered organisations, but also because of instrumental benefits that local officials derive from NGOs (Howell 2019). These include filling gaps in welfare provision or gaining information about citizens' preferences and grievances, especially important given the information deficit that bedevils authoritarian states. But it also reflects NGO survival strategies, including processes of accountability-building that remain an under-researched dimension.

Second, the legal and regulatory environment in China is highly constrictive. The 1998 Regulations on the Management and Registration of Social Organisations establish specific requirements rendering it difficult for NGOs to register and develop organisationally (Saich 2000). In particular the requirement that NGOs identify a supervisory government unit to oversee their work has severely limited the opportunity to register (Hildebrandt 2013; Lu 2009). Government officials concerned about their promotion are reluctant to take responsibility for an NGO, fearing that any potential criminal activity or anti-government agenda could negatively affect their careers. Though these Regulations were amended in 2013 to facilitate the registration of certain types of NGOs such as charities to deliver services, there remain considerable barriers to registration ${ }^{\text {ii }}$. For example, according to Article 3, each location can only have one organisation per domain such as environmental education or poverty alleviation, thus restricting the pluralisation of NGOs (Howell 2003). Similarly, Article 19 stipulates that NGOs can only operate within a defined territory, thus preventing their co-ordinated growth across the country. 
Finally, Chinese NGOs operate in a repressive political context, the contours of which can vary regionally and across time. During Hu Jintao and Wen Jiabao's office (2002-2012) NGOs grew rapidly in number (Wang and Sun 2010), branching into new areas of activities and addressing marginalised interests (Howell 2003; Teets 2009; Wilson 2015). Those working in sensitive areas such as migrant workers or rights issues operated in the interstices of legality, subject to ongoing harassment, but still negotiated hurdles to provide legal advice, services and advocacy (Chan 2012; Cheng et al 2010; $\mathrm{Xu}$ 2013). Though some NGOs registered as companies to avoid restrictive regulations, they were still subject to closure as technically they were non-profit-making agencies. This was a decade where in general associational life blossomed (Howell and Duckett 2019; Lam 2006).

This was to change under the new leadership of Xi Jinping, when in 2015 a wave of suppression targeted feminists, activist lawyers, and migrant workers' rights groups, triggering the most sustained period of repression since 1989. This was followed in 2016 with the passing of a Foreign NGOs Management Law that tightly controlled the inflow of foreign funds to domestic groups (Shieh 2017). Those NGOs that adopt a rights-based approach, touch on sensitive issues or are perceived to have anti-regime agendas, are particularly vulnerable to surveillance and coercion. Furthermore, under the $\mathrm{Xi}$ administration, there has been a determined move to require registered NGOs to establish a party cell, pointing to a further encapsulation of society by the Party. These changes are likely to reduce the survival prospects of unregistered organisations.

However, the Chinese Communist Party (CCP) has not wholly suppressed civic groups, as it has also come to recognise the instrumental benefits of some NGOs to the state. Thus NGO-state relations incorporate complex and subtle processes of negotiating spaces and resources for mutual interests (White et al 1996; Saich 2000). Whilst the state can be repressive, NGOs also depend on the state for access to material resources, policy implementation, state protection and information (Lu 1999: 58-77). The CCP has adopted a two-pronged welfarist incorporation strategy towards civil society - on the one hand suppressing those parts it considers threatening, whilst incorporating others deemed instrumentally useful in welfare reforms and gathering information about citizens' preferences. This dualistic approach towards NGOs is reflected in the 2013 Decision of the $3^{\text {rd }}$ Plenum of the $18^{\text {th }}$ Central Committee of the CCPiii, calling for regulatory changes at national and local levels to contract service-delivery to registered 
social organisations, thus expanding the supply of providers (Howell 2015). Subsequent pilots exposed the weakness of governance, accountability and organisational systems in NGOs. This stimulated debates around the need to 'professionalise' NGOs by improving their accountability and governance (Deng 2003; Li 2003; Li and Hou 2009; Liu 2008).

These particular features of authoritarian regimes create a different dynamic for NGOs in constructing accountability and strengthening legitimacy. In authoritarian regimes empirical analysis of accountability is crucial to understanding the survival and development of NGOs. To this end this article offers a generic framework of analysis as a starting-point for capturing the processes underpinning NGO accountability and legitimacy in an authoritarian regime. This framework emerges out of the empirical fieldwork conducted in China ${ }^{\text {iv }}$.

\section{Framework of analysis}

This section introduces the generic framework and the concepts of first- and secondorder accountability and accountability capital. Table 1 summarises the key elements. NGOs engage in first- and second-order accountability processes that create stocks of accountability capital. These serve as evidence for NGO legitimacy claims, to which they can be held to account. Making accountability is a dynamic process that is performed repeatedly.

The precise combination of elements and the relative weighting given to certain processes is likely to differ between democratic and authoritarian regimes, reflecting the distinctive features of authoritarianism. Thus, compared to a democratic regime, an authoritarian state may involve greater attention to gaining the trust of government officials, who because of less judicial independence, are more able to wield discretion and stymie civil society organisations. Furthermore, we can expect greater attention to highlighting the services dimension of organisations as opposed to rights. Similarly, because of weak civil societies, nurturing public trust through media coverage and display of activities is also likely to be more significant in authoritarian regimes. Also, as authoritarian regimes have more restrictive legal frameworks governing civil society, we can expect considerable efforts to be made to court government officials so as to register. First-order accountability is thus more salient for the survival and development of NGOs in an authoritarian context. 
However, precisely how different elements combine will vary according to context as both authoritarian and democratic regimes vary in the depth of their authoritarianism/democracy, their hybridity and the historical trajectory of state-civil society relations. Whilst all NGOs have to constantly maintain their legitimacy and accountability, in newly democratising regimes or for NGOs undergoing legitimacy repair (Suchman 1995), there is likely as in authoritarian regimes to be greater attention given to garnering government and public trust. 
Table 1: Legitimacy from accountability processes

\begin{tabular}{|c|c|c|c|}
\hline \multirow[b]{2}{*}{$\begin{array}{l}\text { Legitimacy } \\
\text { claims }\end{array}$} & \multicolumn{2}{|c|}{ Source of stocks of accountability capital } & \multirow[b]{2}{*}{ Processes } \\
\hline & $\begin{array}{l}\text { First-order } \\
\text { accountability }\end{array}$ & Second-order accountability & \\
\hline $\begin{array}{l}\text { Efficiency } \\
\text { Effectiveness } \\
\text { Good } \\
\text { governance } \\
\text { Professional- } \\
\text { ism } \\
\text { Values such } \\
\text { as care, } \\
\text { rights, } \\
\text { participation }\end{array}$ & $\begin{array}{l}\text { Mission } \\
\text { statements, } \\
\text { constitution } \\
\text { Audit reports } \\
\text { Reports to } \\
\text { donors, } \\
\text { government } \\
\text { Governance } \\
\text { structures in } \\
\text { place such as } \\
\text { boards, staff } \\
\text { job } \\
\text { specifications } \\
\text { and M\&E } \\
\text { systems, and } \\
\text { clear lines of } \\
\text { authority } \\
\text { User feedback } \\
\text { mechanisms }\end{array}$ & $\begin{array}{l}\text { Positive media coverage } \\
\text { Transparent website and } \\
\text { other public information } \\
\text { such as newsletters } \\
\text { Open days for public and } \\
\text { public events in community. } \\
\text { Evidence of professional } \\
\text { expertise such as training, } \\
\text { practices, membership of } \\
\text { professional networks } \\
\text { Governmental recognition of } \\
\text { work seen in visiting } \\
\text { government delegations, } \\
\text { government awards and } \\
\text { honours and continued } \\
\text { existence despite lack of } \\
\text { legal status } \\
\text { Evidence of expanding } \\
\text { funding } \\
\text { Evidence of growing client } \\
\text { base and domination of a } \\
\text { specific service sector } \\
\text { Evidence of care and respect } \\
\text { seen in staff behaviour and } \\
\text { attitudes } \\
\text { Evidence of participation of } \\
\text { users in providing feedback } \\
\text { and running organisation }\end{array}$ & $\begin{array}{l}\text { Seeking or accepting } \\
\text { opportunities for } \\
\text { media coverage } \\
\text { Developing } \\
\text { transparency and } \\
\text { good governance } \\
\text { practices } \\
\text { Creating websites and } \\
\text { organising public } \\
\text { events around the } \\
\text { NGO } \\
\text { Inviting the public into } \\
\text { the NGO to observe } \\
\text { and enquire about } \\
\text { practices and } \\
\text { approach } \\
\text { Joining professional } \\
\text { bodies, accessing } \\
\text { training opportunities } \\
\text { Delivering reports and } \\
\text { accounts } \\
\text { Receiving government } \\
\text { delegations } \\
\text { Establishing formal } \\
\text { channels for user } \\
\text { participation }\end{array}$ \\
\hline
\end{tabular}


In authoritarian states a restrictive regulatory environment creates barriers to legal status through NGO registration (Dauce 2014; ICNL 2016). Legal status demands first-order accountability as the NGO is answerable to state laws and politicobureaucratic accountability demands through formal accountability processes. Such status can endow the organisation with governmental and public confidence, and for child welfare organisations in China, enables access to various policies that benefit children in their care (Shang and Fisher 2014). Legal status and the associated firstorder accountability is not available to all NGOs, nor is it sufficient to ensure full accountability. Demands for professional, user or democratic accountability tend to rely instead on second-order accountability.

Crafting second-order accountability is crucial to NGO survival and organisational growth in democratic and authoritarian contexts. However, in authoritarian regimes these processes are particularly salient given many NGOs lack legal status and face other threats to their continued existence. Even for registered NGOs, reproducing their legitimacy through second-order accountability can be essential for continued survival. These processes include positive media coverage; informal government recognition through visits by government delegations, awards, financial and/or in-kind support; demonstration of professionalism and service provision, as opposed to activism and rights; transparent processes such as publicising reports, evaluations, and budgetary information; and participatory processes such as involving users in activities.

Just as social capital contributes to building civil society (Putnam 1993), so too accountability capital contributes to NGO legitimacy claims. Stocks of accountability capital gained from first and second-order accountability processes include both formal and informal elements, which can be leveraged as evidence to justify legitimacy claims. Formal elements include auditing reports, donor reports, independent evaluations, annual reports, feedback mechanisms and accountability structures linking to multiple stakeholders along with appropriate sanctions and rewards. Informal elements are evidence that can be leveraged to support claims to be professional, efficient, well governed, caring, and honest. Generally, these are the activities associated with secondorder accountability. These informal accountability processes make available information that can be used for seeking and providing accountability.

In an authoritarian context, these stocks of accountability capital from formal and informal processes are crucial to develop reputation, gain public confidence, attract 
users and seek donor support, and to gain first-order accountability. An NGO that has attracted donor funding suggests that donors have sufficient confidence in the organisation to risk their money and reputation. Having in place governance structures, managerial systems with clear specifications and obligations, and requirements for professional skills development signals to government, the public and funders that an NGO has organisational capacity. An NGO that has developed a large user base, often through referral, suggests sufficient trust in the organisation by the referring organisation.

These stocks of accountability capital from second-order accountability processes are ways through which the organisation can invite accountability with or without legal status. Through varied formal and informal accountability performances of an NGO demonstrates that 'I intend to be accountable to you' and that 'I am a legitimate provider'. Accountability, as Hilhorst (2003) argued, can thus be a device for legitimation.

There is thus a simultaneous and overlapping flow of activities that NGOs undertake to create inputs supporting legitimacy claims and leading to positive outcomes for the NGO, as seen in the ideal type in Figure 1. Where NGOs cannot produce sufficient evidence or become exposed for poor practice, then the outcomes affect their ability to maintain legitimacy claims. In this circular flow NGOs make claims to be legitimate actors in the welfare field. They not only establish formal firstorder processes of accountability but also build reputation to nurture government support, attract donors and service users. For NGOs that strive to be transparent and open second-order accountability is an alternative, supplementary way of informing the public, potential donors and service-users about their work, who can then follow up the information to validate claims.

\section{Put here: Figure 1: Building accountability and legitimacy}

Whilst these processes have to be constantly reproduced, they also take place in a broader set of politics relating to state-NGO, national-international and stakeholder relations (Figure 2). State-NGO politics can involve a politics of divide and rule whereby certain NGOs are tolerated, even courted by the state and others are subject to constant scrutiny. Where courted, state-NGO politics, too, centre around areas of shared interest that benefit citizens. International-national politics revolves around efforts by 
national governments to curtail the influence of foreign agencies suspected of harbouring anti-regime agendas (Dupuy et al 2016; ICNL 2016). However, these politics have to be balanced against the benefits of international engagement such as access to advanced scientific knowledge and expertise and exposure to best international practices. Stakeholder politics concerns the varying powers of different actors which enable them to demand and enforce accountability and impose sanctions. Organised actors such as development agencies and governments leverage greater power than unorganised and marginalised groups such as children, poor women or stigmatised populations. Added to this, changes in the constraints and opportunities for NGOs can alter how NGOs go about building accountability, such as changes in leadership or in regulations.

Put here: Figure 2: Factors shaping processes of crafting accountability and legitimacy

Some stocks of accountability capital are more relevant to some accountproviders than others, though this will vary according to context. For example, open days for the public are a way to demonstrate to the public that they are efficient and professional organisations, contributing to their public legitimacy. They can also serve as evidence to donors that the organisation acts upon claims to be participatory. Similarly, evidence of professional training supports legitimacy claims around professional service provision, enhancing legitimacy in the eyes of users and donors. It is difficult, however, to always provide a one-to-one link between certain accountability capital and the targeted accountability-demander or endower of legitimacy, as accountability in NGOs is both multi-directional and multi-dimensional (Joshi 2013, Mattei 2009). Being accountable along one dimension more than another - such as financial accountability versus user accountability - may bolster or weaken the power of different actors demanding account (Kilby 2006; Mattei 2009; Leung 2008). The framework thus provides for a general relationship but the specific dynamics have to be investigated through particular contexts.

\section{Case studies}

This section illustrates the application of this framework with three cases of child welfare NGOs that have built second-order accountability and bolstered their 
legitimacy, enabling them to develop organisationally despite the considerable barriers. The analysis does not aim to evaluate the accountability processes, nor investigate indepth their political contours. The goal is more modest: to illustrate the processes of accountability-building that can be leveraged for legitimacy claims.

The research draws upon a decade of fieldwork in China from 2007-2017 involving semi-structured interviews in 88 organisations, focus groups, observation of their operations and in-depth case-studies of the selected organisations. A preliminary compilation of a data-set of 188 child welfare organisations provided a sample frame for interviewing organisations operating in various locations ${ }^{\mathrm{v}}$ and for in-depth study of organisations with relatively well developed accountability processes and long operational trajectories $^{\mathrm{vi}}$. They operated in Beijing City, Henan, Hubei and Guangxi provinces where the fieldwork was conducted between 2008 and 2010, with follow-up

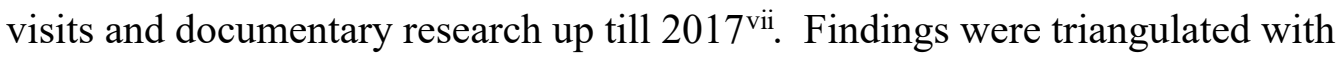
analyses of policy documents, grey and secondary literature, forming the basis for the development of the analytic framework.

The three illustrative case here and the locations where they operated were selected not for their representativeness but because their longer operational trajectory allows us to trace the processes through which they have established more robust accountability systems compared to recently established NGOs in the sample. Indeed, one of these had cared for orphans for many years, but could not register as a child welfare organisation. Like most case-studies, they aim to illustrate the textured processes of change that large-scale quantitative research tends not to capture and do not claim generalisability (Gerring 2007). They reflect varying backgrounds, constraints and routes to accumulating stocks of accountability capital and achieving legitimacy.

Most child welfare NGOs in China have evolved since 2002 with the expansion of associational life during the $\mathrm{Hu}-\mathrm{Wen}$ period, filling significant gaps in state provision (Shang et al 2005). The majority are unregistered and in the early stages of development, with rudimentary systems of accountability. Child welfare NGOs working with orphaned or abandoned children face stricter requirements than most NGOs as they have to obtain permission from three agencies and co-operate with and meet the requirements of relevant state institutions (Shang and Fisher 2014). Crafting accountability has been even more crucial for them in gaining legitimacy amongst government officials and the public, attracting donors and developing a market of service users. 
The three cases are Liming Family, Angel House and Children's Hope Foundation. Liming Family is a faith-based, non-governmental child welfare organisation in Hebei province that has operated as an unregistered orphanage for over 30 years, gaining a national reputation ${ }^{\text {viii }}$. With 32 full-time staff and many volunteers it provides services such as caring for abandoned and orphaned children, adoption, and rehabilitation services for children with disabilities. As a religious organisation, it faced particular constraints related to government suspicion of its purposes and activities. It thus has had to do considerable second-order accountability work to allay government suspicion. Nevertheless through careful navigation of government relations it gained the confidence of local officials aware of significant gaps in welfare provision and pioneered a national network to advance a professional approach to child welfare. With dogged determination, including submitting over 100 petition letters to government departments, it pressed for legal status that would enable citizen rights to the children in its care, such as access to education, residential status and various benefits. Though it finally registered in 2013 as a disability services organisation, it could not register to care for orphans.

Angel House was initiated by the parents of children with cerebral palsy. Our survey revealed that 30 per cent of all registered child welfare organisations were founded by parents of children with disabilities. Located in Guangxi province, Angel House's 25 staff provide services such as rehabilitation and vocational training. Accumulating stocks of accountability capital was crucial to bolstering legitimacy amongst the government and public, expanding its client base, attracting funding and gaining state protection. International professional organisations proved pivotal in strengthening its professional capacities and introducing best international practice. Close to its users, there were stronger incentives to ensure that care was well provided. With direct user participation, the opportunities for informal feedback supplemented its formal mechanisms of accountability. Though it preferred to register as a child welfare organisation offering children certain rights, it could only register as a people's run nonprofit enterprise for services to children with disabilities. Its situation was still precarious as legal status could always be revoked if it lost favour with government officials.

The third case is Children's Hope Foundation in Henan province which transited from a hybrid organisation, both quasi-governmental and quasi-non-governmental, and domestic yet international, to becoming an independent, domestic, non-governmental 
foundation. As a semi-governmental organisation under Association $\mathrm{B}^{\mathrm{ix}}$, it started from an advantageous position as this affiliation endowed it with legal status. However, in seeking to become a fully independent foundation, it had to restock accountability capital to survive. After registration as an independent foundation in 2010, it continued to work in foster care, running homes and facilitating access to health care for children with disabilities. By 2017 it had a staff of 30 .

Having outlined the case-studies, we now use the framework to analyse processes for developing stocks of accountability capital to leverage legitimacy claims. From their documentation, mission statements and interviews, the three cases presented multiple sources of legitimacy relating to values, professionalism and governance. For example, Liming Family emphasised its 'loving' approach and professionalism, whilst Angel House underlined values of care and love, its principled commitment to user participation and professionalism. Children's Hope Foundation presented itself as a professional, value-based organisation, with a 'loving heart' and 'spirit of devotion', deriving from its Christian ethos.

Developing formal and informal elements of second-order accountability was important for unregistered and registered NGOs to gain and maintain government and public trust, attract donor funding and service users. Apart from longer established NGOs, most NGOs in our study lacked formal accountability processes, such as a governing board, annual reports to institutionalised donors, and internal systems such as job specifications and appraisals. In contrast, Liming Family, established a council of members from the church, enterprises, staff, academics and social workers and provided an annual report, work plan and financial statement to church authorities.

Angel House, guided by an international donor, invested considerable energy in formalising and professionalising the organisation. The newly independent Children's Hope Foundation was aware that being efficiently organised was crucial to gaining legitimacy in the eyes of the public and government. It set in place formal systems for greater oversight and efficiency, such as organisational objectives and structure, a board, five-year plan, financial procedures, and provided financial and audit reports to institutional donors and advisory council. Its registration as a people's run nonenterprise unit (minban feiyingli danwei, 民办非营利单位), required annual government inspections and audits, though these were not focussed on professional or child welfare issues. It established a management team to guide operational work and 
develop professional capacity through staff training. Parents received an annual child assessment report to monitor their child's progress.

Apart from these formal mechanisms aimed at the accountability demands of government and donors, the NGOs also invested in informal processes that yielded evidence to be leveraged in support of legitimacy claims. Liming Family used multiple ways to enhance its visibility, solicit funds from the expanding private sector and strengthen its legitimacy. It organised open days for the general public, built partnerships with local businesses and institutions, received local social work students for practical assignments, and mobilised the local community to donate time and in-kind support. It nurtured relations with local media and deployed official festive days to press local government officials to grant it registration and to advocate for the inclusion of people with disabilities in the community.

It also welcomed government delegations to the orphanage, using this opportunity to press for various policy benefits, which their lack of legal status denied them, such as the Five Guarantees allowance, orphan's allowance, and access to local schools for children in its care. Indeed, local officials boosted their own credentials by steering high-level visits to the orphanage because of its reputation for relatively professional care. Such governmental visits signalled informal approval of their work, which was important for legitimacy in the public's and users' eyes. Whilst the local government did not allow Liming Family to register as a child welfare institution, it nevertheless condoned its operation, partly because it did not want to assume responsibility for the children, some of whom came from other provinces for which the local government did not receive any funding. However, such gains were discretionary. For example, having negotiated special case status for adoption purposes, this was later overturned when the local government leadership changed, thus necessitating the rebuilding of legitimacy.

Angel House also deployed a combination of accountability capital to gain legitimacy with the government and public and attract funding by demonstrating its strong emphasis on professionalism and user participation. It placed financial reports on its website, with information about services and costs. Its transparency extended to adopting an open-door approach to users. As parents commented, being invited into the centre to observe their children's rehabilitation, learning to apply some techniques themselves and making use of the Centre's facilities was highly unusual in China. 
As the Director's spouse was a journalist, Angel House was able to mobilise media contacts and promote a favourable public image of its professional approach and user-focus to which it could be held to account. Like Liming Family, it cultivated wider links with individuals and businesses, some of which donated funds, thus gradually bolstering its legitimacy. Its emphasis on user participation gained the confidence of parents, who through everyday encounters with staff could give feedback, query practice, and informally seek explanations of what was being done and why. The continuing emphasis on professional expertise was important not just for building staff capacity but also for enhancing its reputation for professionalism. As a key founder of a nation-wide cerebral palsy learning website, it established a reputation beyond Guangxi province, justifying further its legitimacy as a child welfare provider.

Part of Angel House's success in maintaining registration lay in constant efforts to foster positive relations with local government. Though it had benefited from being one of the first registered disability NGOs in the province, it still had to work hard at maintaining government trust, building its stock of accountability capital. As it grew in scale and reputation, it received a raft of government awards and praise from officials for its achievements. The accumulation of such symbolic inputs added to their stock of accountability and bolstered their legitimacy amongst donors and the public, attracting funding and service users.

Compared to Liming Family and Angel House, the Children's Hope Foundation was in an advantageous position when steering its route to independence as it already had a stock of accountability. It harnessed its close relationships with government officials, international connections, exposure to international best practice, and local and regional networks, to claim legitimacy as a child welfare organisation. However, to raise funds and maintain legitimacy with the public, government and private sector, it also had to restock accountability capital by developing new second-order accountability.

As well as strengthening formal governance mechanisms, it focussed on transparency, public image and displays of professionalism. It used its website to enhance visibility and promote a public image as a well governed, valued-base NGO. By placing audit and annual reports on its website it demonstrated transparency. It publicised its work in the media to develop its public reputation as a competent welfare agency. It highlighted cases of children who needed surgery to attract donations from wealthy entrepreneurs, thus further enhancing its legitimacy with the public. 
The need for more work to improve accountability, such as better monitoring processes, elimination of potential conflicts of interest, and incorporating the voices of service users, was also evident. All the surveyed NGOs, including these three cases, invested more in building accountability capital for government and donor demands, than for children or carers. They had no formal systems and few informal opportunities for accountability to users. Instead they prioritised financial and managerial accountability over user accountability.

\section{Discussion}

Together, these three case-studies exemplified the processes of accumulating stocks of accountability capital that could be used to justify legitimacy claims, particularly for government and donor audiences. As illustrated in figure 1, these processes had positive effects on the development and survival of these cases. In particular they were crucial to fostering public and government trust and confidence as legitimate service-providers and then attracting donations, expanding their client base, and extracting benefits for children in their care and upgrading their professionalism. In all cases developing positive relations with the state was important, not just for material resources but also for legitimacy from the public, who might donate funds or use services. The stocks of accountability capital from informal processes bolstered the formal mechanisms of accountability.

The three NGOs operated in a context of complex politics that both constrained the possibilities for development but also created opportunities. Restrictive registration regulations along with the reluctance of local officials to act as a supervisory agency hampered Liming Family in registering as a child welfare organisation. However it seized the opportunity of new regulations in 2013 to register as a disability services organisation, though this did not resolve all issues such as the citizenship status of the children in its care. Similarly, Children's Hope Foundation used the opportunity from new regulations to register as a foundation. All three organisations benefited from economic growth and the more tolerant approach of some government officials in the $\mathrm{Hu}-\mathrm{Wen}$ period to develop their activities. However, with the new restrictive 2016 Foreign NGO Management law and government suspicion of foreign-funded NGOs, the NGOs faced the risk of less external funding and forfeiting access to international best practice in child welfare and accountability. 
All three case-studies illustrate how building accountability shapes the hierarchy of accountabilities, whereby priority is given to financial and managerial accountability over downward accountability to users. Whilst donors have the power to withdraw funds, users have neither formal mechanisms for seeking accountability nor can they easily exit, in a context where the supply of services is limited. Though a user-initiated NGO such as Angel House created opportunities for parents to give feedback and participate, still, socio-cultural deference to expertise and age affected the hierarchy of accountability. Parents defer to professionals, child service-users defer to adults, and adults too may not recognise children's ability or rights to comment on the services they receive. In the absence of a child rights' movement to advocate for children's rights and empower children, the prospects of user accountability are diminished. This is particularly relevant in authoritarian regimes where governments fear nationwide organising by citizens, and explains in part the lack of articulated accountability demands by users in our study.

\section{Conclusion}

This article set out to develop a generic framework for analysing the processes of building accountability and legitimacy by NGOs. It argued that crafting second-order accountability to develop stocks of accountability capital was crucial for the organisational survival and development of NGOs, particularly those without legal status, and for paving a path towards registration in authoritarian contexts. Even where an independent NGO gained legal status through registration, its continuation was at the discretion of local government officials and subject to political and policy changes. Second-order accountability was particularly salient in authoritarian regimes where the ex-ante elements of accountability such as basic political rights and protections, an enabling regulatory framework, and a vibrant civil society were weak.

NGOs generated evidence that gave substance to their legitimacy claims and provided information to the government, donors, general public and users about their purposes, approach and activities. Whether these processes and the generated evidence directly caused accountability and legitimacy would require a further study, albeit it methodologically difficult to prove. Nevertheless, the success of this continuing, incremental process was reflected in the NGO's development of a client base, acquisition of funding, and achieving and maintaining registration. These processes 
took place in a political context revolving around broader state-NGO relations, domestic and international relations, and power differential amongst stakeholders.

Together, these processes and context shaped the hierarchy of accountabilities that emerged. Specifically, the cases-studies revealed the prioritisation of financial and managerial accountability to donors over democratic accountability to users and staff, a trend observed in democratic regimes, too. However, in an authoritarian state the difficulties of movement-building weakened opportunities for user accountability. Our case-studies of child-welfare NGOs exemplified the unfolding of these processes and resonate more widely with other service-delivery NGOs. For groups working in sensitive areas such as migrants or rights-based advocacy, the constraints on organisational growth are more severe due to government repression. Emphasising services provision over activism and professionalism over rights was important for survival and growth. Whilst the framework sought to capture processes of building accountability, it did not seek to provide an assessment of accountability nor an empirical study of the politics of exercising accountability.

The article contributes not only in developing a generic analytic framework but also in introducing new concepts such as first-order and second-order accountability, and stocks of accountability capital. Though this article focussed on the case of China, the framework could be a useful starting-point for in-depth studies of NGO accountability and legitimacy in other authoritarian regimes. Furthermore, it contributes by drawing attention to the multi-dimensionality and multi-directionality of accountability hierarchies.

Looking ahead to the future in China points to a political context that is more constraining for some NGOs but facilitative for others. The Xi Jinping era has sharpened the application of a welfarist corporatist strategy to civic organising. This strategy in Janus-like fashion encourages the development of service-delivery NGOs that are instrumentally useful to the state but discourages and represses rights-based, advocacy organisations and those deemed to be politically sensitive. Furthermore, tightening state control over foreign funding will reduce the amount of foreign funding which has been a life-line for some NGOs, and reduce avenues for exposure to international best practice in accountability and professional knowledge. The likely expansion of acceptable and politically compliant service-delivery NGOs through governmental contracting raises concerns around the relative independence of NGOs in terms of their declared missions, approaches and activities. It will also require 
adjustments in the strategies NGOs deploy to build accountability and strengthen legitimacy.

\section{References}

Alagappa, M., (1995), Political Legitimacy in Southeast Asia: The quest for moral authority. Palo Alto, C: Stanford University Press

Anderson, K. (2009). What NGO accountability means and does not mean. The American Journal of International Law, 103(1), 170-178

Atack, I. (1999). Four criteria of development NGO legitimacy. World Development, $27(5), 855-864$.

Bebbington, A., Hickey, S., and Mitlin, D. (2008). Introduction: Can NGOs make a difference? The challenge of development alternatives. In Bebbington, A., Hickey, S., and Mitlin, D. (Eds.), Can NGOs Make a Difference? The Challenge of Development Alternatives (pp. 3-37). London: Zed Books.

Bendell, J., and Cox, P. (2006). The donor accountability agenda. In Jordan, L., and Tuijl, P. V. (Eds.), NGO accountability: politics, principles and innovations. London, Earthscan.

Bovaird, T. (2007). Beyond engagement and participation: User and community coproduction of public services. Public administration review, 67(5), 846-860.

Brett, E.A. (2003).Participation and accountability in development management. The Journal of Development Studies, 40(2), 1-29.

Brooker, P. (2000). Non-Democratic Regimes. Theory, Government and Politics. New York: St Martin's Press, Inc.

Bueno de Mesquita, B., Smith, A., Siverson, R.M. and Morrow, J.D., (2003). The Logic of Political Survival. Cambridge, MA: MIT Press

Burnell, P. (2006). Autocratic Opening to democracy: Why legitimacy matters. Third World Quarterly, 27(4), 545-562.

Cassani, A. (2017). Social services to claim legitimacy: comparing autocracies' performance. Journal of Contemporary Politics, 23(3), 348-368.

Chan, Chris King-chi, 2012, Community-based organisations for migrant workers' rights: the emergence of labour NGOs in China, Journal of Community Development, volume 48, number 1, January, pp 6-22 
Cheng, J., Ngok, K.L. and Huang, Y. 2010, 'The survival and development space for China's labour NGOs: informal politics and its uncertainty', Asian Survey, 50 (6), 1082-1106.

Charnovitz, S. (2007). Accountability of non-governmental organisations in global governance. In Jordan, L., and Van Tuijl, P. (Eds.), NGO Accountability. Politics, Principles and Innovations (pp. 21-42). London: Earthscan.

Cornwall, A. and Gaventa, J. 2000, From users and choosers to makers and shapers: Repositioning participation in social policy. IDS Bulletin, 31(4), 50-62

Dauce, F. (2014). The government and human rights groups in Russia: Civilised oppression? Journal of Civil Society, 10(3), 239-254.

Deng, G. (2003). Build up and accountability mechanism for Chinese non-profit organisations. Chinese Public Administration, 3, 28-29.

Douthwaite, M., Hammer, M., and Mayhew, S. (2006). Balancing protection and pragmatism: a framework for NGO accountability in rights-based approaches. Health and Human Rights, 9(2), 180-206.

Dukalskis, A., and Gerschewski, J. (2017). What autocracies say (and what citizens hear): Proposing four mechanisms of autocratic legitimation. Contemporary Politics, 23(3), 251-268.

Dupuy, K., Ron, J. and Prakash, A., 2016. Hands off my regime! Restrictions on foreign aid to non-governmental organisations in poor and middle-income countries, World Development, vol. 84, 299-311

Ebrahim, A., 2003, Making sense of accountability. Conceptual perspectives for Northern and Southern nonprofits, Nonprofit Management and Leadership, Volume 14, Issue 2, 191-212.

Edele, A. (2005). Non-Governmental Organizations in China. Geneva: Centre for Applied Studies in International Negotiations (CASIN). Retrieved from http://www.casin.ch/web/pdf/chinafinal.pdf.

Edwards, M., and Hulme, D. (Eds.) (1995). Non-Governmental Organisations Performance and Accountability: Beyond the Magic Bullet. London: Earthscan.

Gandhi, J. (2008). Political Institutions under Dictatorship. Cambridge: Cambridge University Press.

Gerring, J., (2007).Case Study Research: Principles and Practices. New York: Cambridge University Press. 
Goetz, A., and Jenkins, R. (2005). Reinventing Accountability: Making Democracy Work for Human Development. Basingstoke: Palgrave Macmillan.

Hildebrandt, T. (2013). Social Organisations and the Authoritarian State in China. Cambridge: Cambridge University Press.

Hilhorst, D. (2003). The Real World of NGOs. London: Zed Books.

Holbig, H., 2013, Ideology after the end of ideology. China and the quest for autocratic legitimation, Democratisation, 20(1), pp 61-81

Howell, J. (2019). NGOs and Civil Society: The Politics of Crafting a Civic Welfare Infrastructure in the Hu-Wen period, The China Quarterly, March, number 237, pp 58-82.

Howell, J. (2015). Shall we dance? Welfarist incorporation and the politics of statelabour NGO relations. The China Quarterly, 223, 702-723.

Howell, J., (2003), New Directions in Civil Society: Organising around Marginalised Interests, pp 143-171 in Jude Howell (editor) Governance in China, Rowman and Littlefield Publishers, Inc., Boulder

Howell, J. and Duckett, J.(2019) Reassessing the Hu-Wen Era: A golden age or lost decade for social policy in China?, The China Quarterly, number 237, 1-14.

Howell, J., Shang, X. and Fisher, K.R. (2018), NGOs and Accountability in ChinaChild Welfare Organisations, Palgrave Macmillan, UK.

ICNL, 2016, Survey of Trends Affecting Civil Space: 2015-2016, Global Trends in NGO Law, volume 7, issue 4, September, www.icnl.org/research/trends/index.html, accessed 10/05/2018

International Development Committee, 2018, Sexual Exploitation and Abuse in the Aid Sector, UK Parliament https://publications.parliament.uk/pa/cm201719/cmselect/cmintdev/840/84004.h

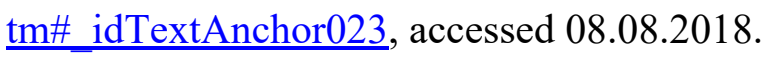

Joshi, A. (2013), 31(S1), Do They Work? Assessing the Impact of Transparency and Accountability Initiatives in Service Delivery, Development Policy Review, S29S48.

Kailitz, S., (2013). Classifying political regimes revisited: Legitimation and durability, Democratisation,20(1), pp 39-60

Kilby, P. (2006). Accountability for empowerment: Dilemmas facing non-governmental organizations. World Development, 34(6), 951-963. 
Lam, Willy Wo-Lap. 2006. Chinese Politics in the Hu Jintao Era: New Leaders, New Challenges. Abingdon: Routledge.

Leung, T.T.F. 2008, Accountability to Welfare Service Users: Challenges and Responses of Service Providers, British Journal of Social Work, 38, 531-545.

Li, H. (2003). On construction of the public accountability of non-profit organisations. Journal of Shanghai Jiaotong University (Edition of Philosophy and Social Sciences), 11(1), 32-36.

Li, S., and Hou, J. (2009). Problems in the accountability of Chinese non-profit organisations and countermeasure. Journal of China National School of Administration, 6, 49-53.

Liu, J. (2008). Complete the accountability mechanism of Chinese non-profit organisations. Hubei Social Sciences, 5, 42-44.

Lu, Yiyi (2009). Non-governmental Organisations in China., Abingdon: Routledge.

Ma, J. (2012). The rise of social accountability in China. Australian Journal of Public Administration, 71(2), 111-121.

Ma, J. (2009). The Dilemma of Developing Financial Accountability without Election A Study of China's Recent Budget Reforms, The Australian Journal of Public Administration, vol. 68, no. S1, S62-S72.

Mattei, P. (2009). Restructuring Welfare Organizations in Europe, from Democracy to Good Management? London: Macmillan.

Morcol, G. and G. Mudacumura (eds), 2014. Challenges to Democratic Governance in Developing Countries,. Springer International Publishing.

Najam, A. (1996). NGO accountability: A conceptual framework, Development Policy Review, 14 (4), 339-353

Putnam, R. (1993), Making Democracy Work: Civic Traditions in Modern Italy. Princeton, Princeton University Press.

Saich, A. (2000). Negotiating the State: The Development of Social Organisations in China. The China Quarterly. Volume 161, 124-141.

Scholte, J.A. (2011). Building Global Democracy? Civil Society and Accountable Global Governance. Cambridge: Cambridge University Press.

Shang, X., Wu, X., and Wu, Y. (2005). Welfare provision to vulnerable children: the missing role of the state. The China Quarterly, 181, 122-36.

Shang, X., and Fisher, K.R. (2014). Caring for Orphaned Children in China, Lexington Books, Lanham. 
Shieh, S. (2017). The Origins of China's New Law on Foreign NGOs, China File, Available at: http:/www.chinafile.com/reporting-opinion/viewpoint/origins-ofchinas-new-law-foreign-ngos. Accessed 30 August, 2017.

Speer, J. (2012). Participatory governance reform: a good strategy for increasing government responsiveness and improving public services? World Development, 40(12), 2379-2398

Suchman, M.C. (1995). Managing Legitimacy: Strategic and Institutional Approaches. The Academy of Management Review, 20(3), 571-610.

Teets, J.C. (2009). Post-earthquake relief and reconstruction efforts: The emergence of civil society in China?, The China Quarterly, 198, 330-347.

Wang, M., \& Sun, W. (2010). Trends and characteristics in the development of China's social organizations. The China Nonprofit Review, 2(2), 153-176.

White, G., Howell, J., and Shang, X. (1996). In Search of Civil Society: Market Reform and Social Change in Contemporary China. Oxford: Clarendons Press.

Willems, T., and Van Dooren, W. (2007). Coming to terms with accountability: Combining multiple forums and functions. Public Management Review, 14(7), 1011-1036.

Wilson, Scott, 2015, Tigers without teeth. The pursuit of justice in contemporary China, Lanham, Rowman and Littlefield.

Wintrobe, R. (1998). The Political Economy of Dictatorship. Cambridge: Cambridge University Press.

Wong, John and Lai Hongyi (eds.). 2006. China into the Hu-Wen Era: Policy Initiatives and Challenges. Singapore: World Scientific Publishing

World Bank. (2004). World Development Report 2004: Making services work for poor people. Washington, DC: World Bank.

$\mathrm{Xu} \mathrm{Li}, 2013$, Labour non-governmental organisations in China: Mobilising rural migrant workers, Journal of Industrial Relations, 55, 2, pp 243-259

$\mathrm{Xu}, \mathrm{X}$. (2012). On the new model of public participation models in the micro-blog era: take Guo Meimei as an example. Lanzhou Academic Journal, 2(1), 66-71.

Yang Guobin, 2006, The Internet and Civil Society in China: Co-evolutionary Dynamics and Digital Formations, chapter 11, pp 303-318 in Lowell Dittmer and Guoliu Li (eds), Domestic Politics in Transition. China's Deep Reform, Rowman and Littlefield Publishers, Inc., Lanham, Boulder 
Yin Pumin. 2011. A New Dawn for NGOs. Registration requirements relaxed for charity work. Beijing Review, Number 31 . August $4^{\text {th. }}$

${ }^{\mathrm{i}}$ Such assertions tend to be based on anecdotal evidence and available data-sets of NGOs compiled by researchers, though due to lack of registration precise statistics are inevitably difficult to collate.

${ }^{i i}$ Experiments with this had already begun in 2010 in Beijing (Yin 2011).

${ }^{\text {iii }}$ See Section XIII Making Innovations in the Social Governance System.

iv The framework and empirical evidence are explained further in Howell et al. (2018)

${ }^{\mathrm{v}}$ The sample frame was used to select organisations of varying size, registration status etc ,as indicated in endnote (v), operating in locations with a minimum of seven child welfare organisations.

${ }^{\mathrm{vi}}$ This data-set yielded basic information such as size, registration status, funding, domain and place of activity, and date of establishment.

${ }^{\text {vii }}$ We are grateful to the Australian Research Council (ARC) for funding this research and the ESRC/ARC linking arrangement that facilitated international collaboration.

viii Over $60 \%$ of non-governmental adoption agencies are run by faith-based organisations.

ix The Association is not named to protect confidentiality. 